\title{
OPTIMASI PRODUKSI GAULTHERIN DARI GANDAPURA DENGAN TEKNOLOGI MIXED-DRYING EXTRACTION
}

\author{
PRIYONO KUSUMO ${ }^{1}$, MOHAMAD ENDY YULIANTO ${ }^{2}$, DAN MF SRI MULYANINGSIH ${ }^{1}$ \\ ${ }^{1}$ Jurusan Teknik Kimia UNTAG Semarang \\ Jl. Pawiyatan Luhur Bendan Dhuwur Semarang 50233 \\ ${ }^{2}$ Jurusan Teknik Kimia Fakultas Teknik UNDIP \\ Jl. Prof Sudarto SH, Pedalangan Tembalang, Semarang 50239 \\ Surel: priyo330@yahoo.com
}

\begin{abstract}
ABSTRAK
Tujuan studi ini adalah menentukan optimasi produksi gaultherin dari gandapura melalui teknik inaktivasi enzim gaultherase dengan teknologi mixed-drying extraction. Kegiatan riset meliputi studi produktifitas gaultherin dan optimisasi parameter-parameter proses. Upaya yang dapat meningkatkan produktifitas gaultherin diantaranya pengaruh penambahan drying agent (magnesium sulfat, sodium sulfat, kalsium klorida, dan kalsium sulfat). Optimisasi dilakukan menggunakan faktorial design $2^{n}$. Penentuan variabel berpengaruh dengan menggunakan normal probability plot, setelah dilakukan perhitungan main efek dan perhitungan interaksi. Selama riset, diukur kandungan gaultherin, metil salisilat, asam salisilat menggunakan spektrofotometer maupun HPLC-MS. Hasil riset menunjukkan bahwa meningkatnya konsentrasi drying agent maupun etanol menyebabkan perolehan gaultherin semakin besar, terutama dengan penambahan kalsium klorida. Hasil telaah menyatakan bahwa variabel proses mixed-drying extraction untuk inaktivasi enzim gaultherase yang paling berpengaruh adalah $p H$ dan konsentrasi etanol. Semakin besar pH ekstraksi, akan meningkatkan perolehan senyawa aktif gaultherin. Kondisi optimum mixed-drying extraction untuk inaktivasi enzim tercapai pada $\mathrm{pH} 8$ dengan kadar senyawa aktif gaultherin sebesar 14,46\%. Semakin besar konsentrasi pelarut, gaultherin yang terekstrak semakin meningkat. Produksi gaultherin secara maksimum tercapai pada konsentrasi etanol $90 \%$ dengan perolehan senyawa aktif sebesar $13,10 \%$.
\end{abstract}

Kata kunci: drying agent, ekstraksi, gandapura, gaultherin, inaktivasi enzim

\begin{abstract}
This study purposed the optimization of gaultherin production from "gandapura" by inactivating the gaultherase enzyme, including gaultherin productivity and process parameters. This research applied the combination processes of extraction-dryer, simultanously. The productivity of gaultherin was improved by adding the drying agent, such as magnesium sulfate, sodium sulfate, calcium chloride, and calcium sulfate. The optimization was conducted using a factorial design $2 n$. Dependent variables determined by calculating the main effects and interactions, following by the application of probability plots. During the research, the content of gaultherin, methyl salicylate, salicylic acid were measured by using a spectrophotometer and HPLC-MS. The results shows that the higher concentration of drying agent (especially calcium chloride) and ethanol, increased the content of gaultherin. However, the most influenced factor to this conducted process was $p H$, regarding to the concentration of ethanol. During extraction, the higher the $p H$, increased the active compound of gaultherin. The optimum condition of enzyme inactivation was found at $p H 8$ with the content of gaultherin at $14.46 \%$. The higher the solvent concentration of ethanol, the higher content of gaultherin can be extracted. The maximum process condition regarding to ethanol concentration found at $90 \%$ with active compound concentration at $13.10 \%$.
\end{abstract}

Keywords : drying agent, extraction, gandapura, gaultherin, enzyme inactiavtion 


\section{PENDAHULUAN}

Gandapura merupakan salah satu tanaman penghasil minyak atsiri yang masuk dalam daftar Komoditi Binaan Direktorat Jenderal Perkebunan berdasarkan Keputusan Menteri Pertanian nomor 511/kpts/pd.310/9/2006. Gandapura (Gaultheria fragantissima) dapat tumbuh pada dataran tinggi, 1300-3300 meter dpl (Hernani, 2004). Selama ini gandapura belum dikembangkan secara ekonomis dan tumbuh liar didaerah pegunungan diantaranya di Gunung Lawu, Tawangmangu, dan Wonosobo, Dieng. Salah satu industri penghasil minyak gandapura yang ada di Wonosobo adalah Kelompok Tani Rukun yang berlokasi di Desa Sikunang, Kecamatan Kejajar, Kabupaten Wonosobo. Minyak gandapura memiliki kandungan metil salisilat antara 9398\%. Namun demikian, minyak gandapura yang dihasilkan Kelompok Tani di Indonesia hanya memiliki kandungan metil salisilat $82,23 \%$ (Mauludi, 2003). Di sisi lain kendala utama yang dihadapi kelompok-kelompok tani penyuling minyak gandapura saat ini, adalah bahwa minyak gandapura tidak lagi kompetitif di pasaran mengingat Cina sudah bisa memproduksi minyak gandapura sintetis (Manurung, 2002). Oleh karenanya, perlu pengembangan diversifikasi produk dari tanaman gandapura.

Diversifikasi produk dari gandapura pada dasarnya bisa berupa produksi gaultherin. Produk gaultherin memiliki nilai ekonomis yang jauh lebih tinggi jika dibandingkan dengan minyak gandapura. Karena harga minyak gandapura sebesar 22 dolar tiap $15 \mathrm{ml}$, sedangkan $10 \mathrm{mg}$ gaultherin seharga 690 dolar. Analisis teoritis menunjukkan bahwa produktivitas gaultherin sekitar 12 kali lebih tinggi dibandingkan produksi minyak gandapura yang dihasilkan Kelompok Tani di Indonesia. Namun, produksi gaultherin dari tanaman gandapura di Indonesia, sampai saat ini belum dikomersialkan. Gandapura merupakan spesies tanaman yang mengandung total salisilat dengan konsentrasi sangat tinggi. Konsentrasi salisilat gandapura 20 kali lebih besar dibanding konsentrasi salisilat yang ditemukan pada Filipendula dan 100 kali lebih besar dari konsentrasi salisilat pada Lemon Thyme. Kandungan total salisilat beberapa tanaman disajikan pada Tabel 1. Sebagian besar salisilat yang terdapat pada tanaman gandapura berada dalam bentuk aktif yang disebut gaultherin, yang merupakan konjugasi metil salisilat dengan disakarida. Ketika jaringan tumbuhan tersebut rusak atau terkoyak, gaultherin akan terhidrolisa secara enzimatis menjadi metil salisilat dan terlepas. Proses ini diduga merupakan bagian sistem pertahanan dari tumbuhan gandapura.

Gaultherin memiliki sifat-sifat yang menjadikannya sebagai kandidat terbaik natural aspirin, anti kanker, anti inflamatory, dan cardiopulmonary (Ribnicky et al., 2003). Secara empirik tanaman dari keluarga gaultheria telah digunakan dalam pengobatan kanker dan leukimia (Hoffman, 2007). Tanaman yang berasal dari gaultheria juga dilaporkan memiliki sifat sebagai senyawa antikarsinogenik. Sebagai natural aspirin, gaultherin memiliki daya sembuh yang sama dengan aspirin sintetis namun memiliki efek negatif yang minimal. Saat ini, aspirin (Acetylsalicylic acid) merupakan obat yang paling banyak dikonsumsi oleh penduduk dunia karena sifat dan fungsinya sebagai anti piretik, anti inflamatory, dan analgesik (Linjakumpu et al., 2002). Oleh karenanya, diperkirakan

Tabel 1. Konsentrasi Salisilat pada Beberapa Tanaman

\begin{tabular}{lcc}
\hline \multicolumn{1}{c}{ Spesies Tanaman } & $\begin{array}{c}\text { Salisilat bebas } \\
\text { (ug/mg FW) }\end{array}$ & $\begin{array}{c}\text { Salisilat Total } \\
\text { (ug/mg FW) }\end{array}$ \\
\hline Lemon Thyme & 1,55 & 42,32 \\
French Thyme & 0,33 & 13,26 \\
Lavender & 0,28 & 6,14 \\
Rosemary & 0,58 & 3,84 \\
Gandapura & $\mathbf{1 9 , 0}$ & $\mathbf{5 7 7 0}$ \\
\hline
\end{tabular}


kebutuhan industri farmasi dunia terhadap gaultherin akan meningkat pada tahun-tahun mendatang. Meskipun demikian, sampai saat ini belum ada metode pengambilan gaultherin yang efektif dari tanaman gandapura. Kesulitan yang dialami dalam proses pengambilan gaultherin adalah selama proses ekstraksi, dengan rusaknya jaringan, maka gaultherin akan dengan segera terhidrolisa menjadi komponen-komponen individualnya yaitu metil salisilat dan disakarida. Proses hidrolisa tersebut diyakini dikatalisasi oleh enzim yang terdapat dalam tanaman itu sendiri yaitu gaultherase (U.S. Paten No. 2002/0031562 A1). Untuk mengatasi hal ini, perlu dicari metode guna mengekstraksi gaultherin dari tanaman pada kondisi dimana aktivitas gaultherase minimal atau inaktif. Dengan demikian reaksi hidrolisa gaultherin menjadi metil salisilat dan disakarida tidak akan terjadi.

Metode pengambilan gaultherin yang terdapat pada Gaultheria procumbens hanya dapat diekstrak jika gaultherin tidak terhidrolisa oleh enzim gaultherase. Aktivitas gaultherase terhambat dengan penambahan senyawa polar. Penambahan etanol mampu menghambat aktivitas gaultherase (U.S. Paten No. 2002/0031562 A1, Kusumo dkk., 2013). Beberapa jenis senyawa kimia lain juga mampu menghambat aktivitas enzim gaultherase, antara lain methylen klorida, acetonitril maupun air panas (U.S. Paten No. 7.033.618). Teknik inaktivasi enzim gaultherase dan ekstraksi gaultherin secara simultan dengan pelarut etanol perlu dikaji untuk produksi gaultherin dari gandapura. Pelarut etanol akan berfungsi ganda, yaitu inaktivasi enzim sekaligus mengekstrak gaultherin. Studi fundamental perpindahan massa telah dilakukan untuk recovery gaultherin melalui proses ekstraksi (Kusumo dkk., 2013). Hasil kajian menunjukkan, bahwa inaktivasi enzim gaultherase yang berada dalam gandapura menggunakan pelarut etanol sangat potensial dan prospektif, karena mampu meningkatkan perolehan senyawa aktif gaultherin hingga mencapai $10 \%$. Namun demikian, gaultherin yang terekoveri belum bisa dihasilkan secara maksimal.
Hal ini disebabkan oleh: (i) mekanisme difusi pelarut etanol ke dalam sitoplasma tanaman gandapura sedikit tertahan sel selular, sehingga tidak semua enzim gaultherase mengalami proses unfolding, (ii) reaksi hidrolisa gaultherin menjadi metil salisilat dan disakarida masih tetap terjadi, dan (iii) produk gaultherin berupa serbuk padat relatif kurang stabil.

Pengembangan proses ekstraksi dan drying agent secara simultan merupakan inovasi untuk meningkatkan produksi gaultherin. Keunggulan proses ini adalah mampu meringkas tiga proses sekaligus dalam satu tahapan meliputi proses inaktivasi enzim gaultherase, proses ekstraksi, dan proses dehidrasi osmosis. Modifikasi ekstraktor berfungsi sebagai inaktivasi enzim gaultherase dan perusakan sel selular, agar recovery gaultherin maksimal. Sedangkan drying agent berfungsi sebagai pengering secara osmosis, yaitu proses pengambilan air dari suatu bahan yang dilakukan dengan menempatkan bahan pada larutan berkonsentrasi tinggi dimana diantara keduanya terdapat membran semipermiabel. Akibatnya kemungkinan terjadinya reaksi hidrolisa gaultherin menjadi metil salisilat relatif rendah. Skema proses ekstraksi dan dehidrasi osmosis simultan ini diharapkan dapat memberikan sedikitnya lima keuntungan, yaitu (i) enzim gaultherase mengalami unfolding, akibatnya akan mereduksi reaksi hidrolisa gaultherin menjadi metil salisilat yang dikatalisis oleh enzim gaultherase, (ii) yield gaultherin meningkat, karena degradasi sel selular oleh penetrasi etanol, (iii) kebutuhan energi untuk inaktivasi enzim dan pengambilan gaultherin lebih sedikit, (iv) beban pemurnian produk lebih ringan, dan (v) jumlah limbah sedikit. Semua keuntungan ini akan mereduksi biaya produksi. Meskipun demikian, problem utamanya adalah bagaimana mengkondisikan supaya laju difusi etanol ke dalam sitoplasma (enzim gaultherase) seoptimal mungkin, sehingga dapat memperluas penetrasi pelarut ke sisi aktif enzim disamping mereduksi terseretnya fasa diluen ke fasa kontinyu. Untuk itu, fokus penelitian diarahkan guna menentukan optimisasi paramater-paramater proses yang 
sangat penting peranannya sebelum diterapkan secara komersial.

\section{METODE}

Penelitian tentang inaktivasi enzim gaultherase melalui teknologi mixed-drying extraction untuk produksi gaultherin diinvestigasi secara eksperimen dan pemodelan. Penelitian dilaksanakan selama 10 bulan. Kegiatan yang dilakukan antara lain: studi produktivitas gaultherin dan studi optimisasi parameterparameter proses.

\section{Studi Produktifitas Gaultherin}

Studi produktifitas gaultherin dilakukan selama 2 bulan di Laboratorium Teknik Separasi UNTAG Semarang dan Laboratorium Bioteknologi Teknik Kimia PSD III UNDIP. Usaha-usaha yang dapat meningkatkan produktifitas diantaranya pengaruh penambahan drying agent (sodium sulfat, kalsium klorida, dan kalsium sulfat) terhadap proses mixed-drying extraction. Secara umum tingkat produktifitas gaultherin akan lebih baik dengan adanya penambahan drying agent. Penggunaan drying agent bermanfaat mengikat, mengurangi maupun menghilangkan kandungan air dalam larutan maupun dalam campuran air sehingga tidak terjadi reaksi hidrolisa gaultherin oleh enzim gaultherase. Diharapkan dengan penambahan drying agent, yield yang diperoleh pada produksi gaultherin akan lebih tinggi bila dibandingkan proses produksi tanpa penambahan drying agent.

\section{Bahan dan Alat Penelitian}

Bahan baku yang digunakan dalam penelitian ini adalah daun dan bunga tanaman gandapura yang diperoleh dari Kelompok Tani Rukun di Desa Sikunang Wonosobo. Bahan baku tersebut dibekukan guna menghambat aktifitas enzim gaultherase. Bahan lain yang diperlukan adalah etanol sebagai pelarut etanol, $\mathrm{pH}$ buffer, drying agent (gelatin, kalsium klorida dan sodium sulfat), serta bahan untuk keperluan analisis kadar gaultherin, kadar asam salisilat dan

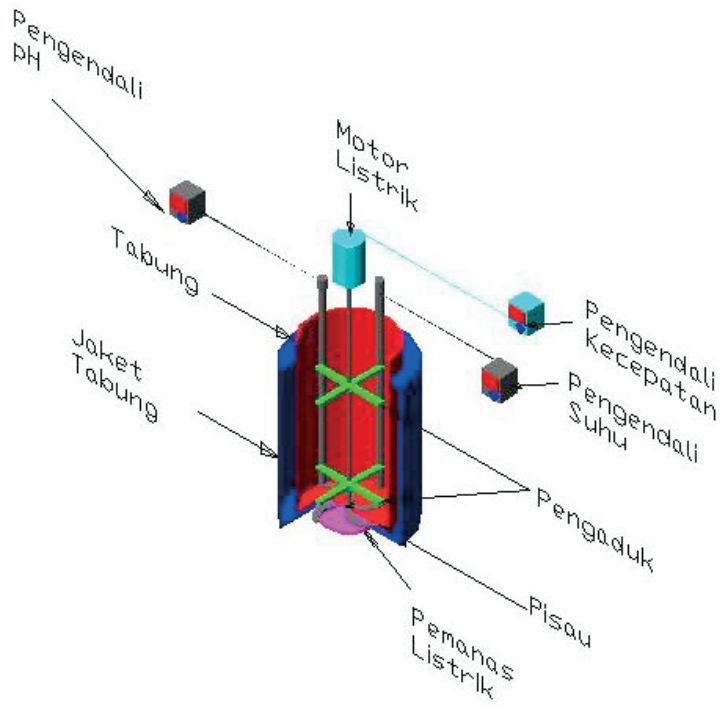

Gambar 1. Mixed-Drying Extraction

kadar metil salisilat. Penentuan kadar gaultherin dilakukan menggunakan metode analisis HPLCMS.

Peralatan utama yang dipakai pada riset adalah ekstraktor dan dehidrasi osmosis satu tahap yang digunakan untuk inaktivasi enzim, mereduksi air, dan mengekstrak gaultherin. Mixed-drying extraction memiliki karakteristik multi fungsi, yaitu mampu meringkas tiga tahapan proses dalam satu alat, yaitu proses inaktivasi enzim, proses ekstraksi gaultherin, dan proses dehidrasi osmosis. Mixed-drying extraction berupa tangki berpengaduk yang dilengkapi dengan blade/pisau pencacah seperti halnya pada blender. Rangkaian alat ekstraktor dan dehidrasi osmosis satu tahap yang digunakan untuk produksi senyawa aktif gaultherin tersaji pada Gambar 1. Rangkaian alat ini terdiri dari ekstraktor inaktivasi enzimatis yang dilengkapi motor pengaduk, blade pencacah, pengendali suhu, dan pengendali putaran pengaduk. Alat penunjang yang diperlukan meliputi: filtrasi, oven, centrifugasi, dan heater untuk membantu penentuan kadar asam salisilat dan kadar metil salisilat. Identifikasi dan analisis gaultherin dilakukan menggunakan spektrofotometer maupun menggunakan HPLC-MS. 


\section{Variabel Percobaan}

Rasio pelarut-umpan pada 10:1, suhu pengeringan produk $80^{\circ} \mathrm{C}, \mathrm{pH}$ larutan 4,8 , kecepatan putar pengaduk 75rpm, kecepatan putar pisau pencacah 125rpm, waktu ekstraksi 60menit, dan konsentrasi etanol 80, 85, 90, 95\%. Jenis drying agent meliputi: sodium sulfat, kalsium klorida, dan kalsium sulfat. Konsentrasi drying agent pada $10 ; 15 ; 20 ; 25 \%$ (b/b).

\section{Prosedur Percobaan}

Daun dan bunga tanaman gandapura dibekukan menggunakan es atau nitrogen cair. Ekstraksi dan dehidrasi osmosis dilakukan dalam mixed-drying extraction. Alat mixed-drying extraction dilengkapi blade atau pisau pencacah di bagian bawah. Rasio pelarut : umpan, 10:1. Etanol yang ditambahkan adalah etanol dengan konsentrasi 90\%. $\mathrm{pH}$ larutan dijaga pada $\mathrm{pH}$ 4,8 menggunakan buffer $\mathrm{pH}$. Kecepatan putar pengaduk dan kecepatan putar pisau pencacah masing masing 75 dan $125 \mathrm{rpm}$. Drying agent ditambahkan sesuai dengan variabel percobaan. Ekstraksi dilangsungkan selama 60menit. Padatan kemudian dipisahkan dari ekstrak menggunakan filter atau sentrifugasi. Ekstrak yang telah terpisah dari padatannya kemudian ditambahkan dengan bahan kimia atau dipanaskan guna menghilangkan pelarut. Untuk mendapatkan gaultherin dalam bentuk larutan, ekstrak yang telah dipanaskan dapat diresuspensi menggunakan buffer atau air. Hasil ekstraksi kemudian dianalisis kandungan metil salisilat, asam salisilat menggunakan metode analisis dilute isotop stabil dan kandungan gaultherinnya menggunakan HPLC-MS.

\section{Penentuan Yield}

Komposisi gaultherin diukur dengan HPLCMS. Faktor konversi dihitung berdasar gaultherin yang terbentuk terhadap daun dan bunga tanaman gandapura yang digunakan. Kadar gaultherin diukur menggunakan HPLC-MS. Kadar air diukur dengan penentuan kadar air manual. Berat jenis diukur dengan piknometer, dan indeks bias diukur dengan refraktometer.

\section{Penentuan Variabel Berpengaruh}

Penentuan variabel berpengaruh dilakukan selama 3 bulan di Laboratorium Teknik Separasi Teknik Kimia UNTAG Semarang dan Laboratorium Bioteknologi Teknik Kimia PSD III UNDIP dengan menggunakan experimental design yakni metode faktorial desain $2^{\mathrm{n}}$. Parameter-parameter yang diteliti adalah waktu inaktivasi, pengaruh rasio solvent-gandapura, konsentrasi etanol, konsentrasi drying agent, dan kecepatan putar pencacah kecepatan putar pengaduk. Variabel pada penentuan variabel berpengaruh disajikan pada Tabel 2. Analisis data pada penentuan variabel yang berpengaruh dapat menggunakan normal probability plot, setelah dilakukan perhitungan efek utama dan perhitungan interaksi dengan menggunakan program statistik Matlab ${ }^{\circledR}$.

\section{Variabel Percobaan}

Kecepatan putar pengaduk ditetapkan pada putaran 75rpm, sedangkan kecepatan putar pisau pencacah sebesar 125rpm. Jenis drying agent 2 Kas Kosong sesuai data dari studi produktifitas dan suhu pengering ditetapkan pada $80^{\circ} \mathrm{C}$. Penentuan variabel berpengaruh

Tabel 2. Data Batas Variabel pada Penentuan Variabel Berpengaruh

\begin{tabular}{lcc}
\hline \multicolumn{1}{c}{ Variabel } & Batas Bawah & Batas Atas \\
\hline Waktu (A) & 60 menit & 180 menit \\
pH larutan (B) & 7 & 9 \\
Rasio solvent-daun gandapura (C) & $10: 1$ & $20: 1$ \\
Konsentrasi etanol (D) & $80 \%$ & $95 \%$ \\
Konsentrasi drying agent $(\mathrm{E})$ & $10 \%(\mathrm{~b} / \mathrm{b})$ & $25 \%(\mathrm{~b} / \mathrm{b})$ \\
\hline
\end{tabular}


meliputi: waktu, $\mathrm{pH}$ larutan yang dikendalikan dengan penambahan buffer, rasio pelarut-daun gandapura, konsentrasi etanol, dan konsentrasi drying agent. Variabel berpengaruh ditentukan dengan menggunakan metode faktorial desain, berdasarkan batas bawah dan batas atas. Data batas masing-masing variabel disajikan pada Tabel 2.

\section{Experimental Design}

Analisis data pada penelitian ini menggunakan sistem faktorial desain yang berarti sekumpulan percobaan yang dirancang untuk memperoleh data-data konkret untuk membuktikan suatu hipotesa. Pada desain eksperimental setiap variabel yang diuji ditentukan pada beberapa harga, biasanya dua harga untuk variabel bebas. Hasil percobaan dengan menggunakan factorial design dua level, dilakukan analisis regresi terhadap harga efek interaksi dan persentase probabilitas, sehingga variabel berpengaruh pada proses ekstraksi gaultherin dapat ditentukan.

\section{Optimisasi Parameter Proses}

Penelitian ini bertujuan untuk mencari kondisi optimal untuk produksi gaultherin dari gandapura melalui proses inaktivasi enzim gaultherase dengan mixed-drying extraction. Proses optimasi parameter proses dilaksanakan selama 2 bulan di Laboratorium Teknik Separasi Teknik Kimia UNTAG Semarang dan Laboratorium Bioteknologi Teknik Kimia PSD III UNDIP. Tahap ini adalah melakukan optimasi terhadap variabel berpengaruh. Tetapan pada optimasi parameter proses adalah tetapan pada penentuan variabel berpengaruh Kecepatan putar pengaduk $75 \mathrm{rpm}$, kecepatan putar pisau pencacah $125 \mathrm{rpm}$, jenis drying agent sesuai data dari studi produktifitas, suhu pengeringan $80^{\circ} \mathrm{C}$, dan parameter lain selain variabel paling berpengaruh. Sebagai variabel dalam percobaan, ditentukan dengan membuat interval tertentu pada variabel berpengaruh.

\section{Telaah Pemodelan Regresi pada Kondisi Optimum}

Kegiatan pemodelan diawali dengan menyusun persamaan matematis dengan regresi berdasarkan data dari studi optimisasi parameter proses. Model regresi mewakili variabel proses mixed-drying extraction pada keadaan optimum dan digunakan untuk memprediksikan kondisi serta evaluasi kinerja alat proses.

\section{HASIL DAN PEMBAHASAN}

Ekstraksi tanaman gandapura menggunakan senyawa polar berupa etanol berfungsi ganda, yaitu menginaktifkan enzim gaultherase dan mengekstrak senyawa aktif gaultherin. Difusi etanol ke dalam daun gandapura (Gambar 2) bertujuan agar enzim gaultherase yang berada dalam sitoplasma berpenetrasi dengan pelarut, sehingga menyebabkan aktivitas enzim terhambat. Pernyataan ini juga diungkapkan oleh Poulev dkk. (2003) bahwa aktivitas gaultherase terhambat dengan penambahan senyawa polar. Mekanisme selanjutnya bahwa pelarut etanol akan menyusup menembus dinding membran

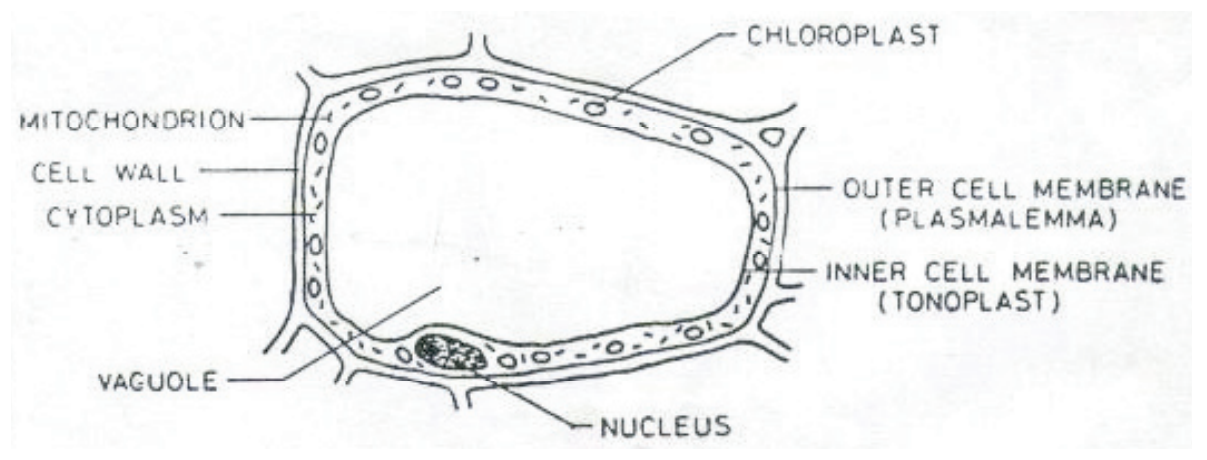

Gambar 2. Sel Daun Gandapura 


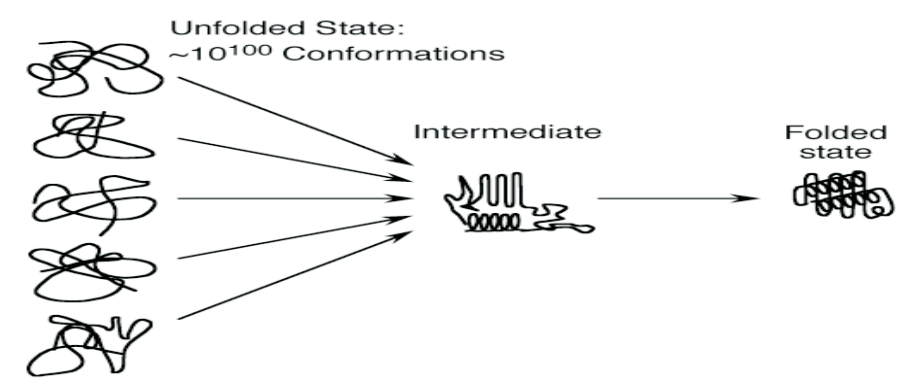

Gambar 3. Proses Folding

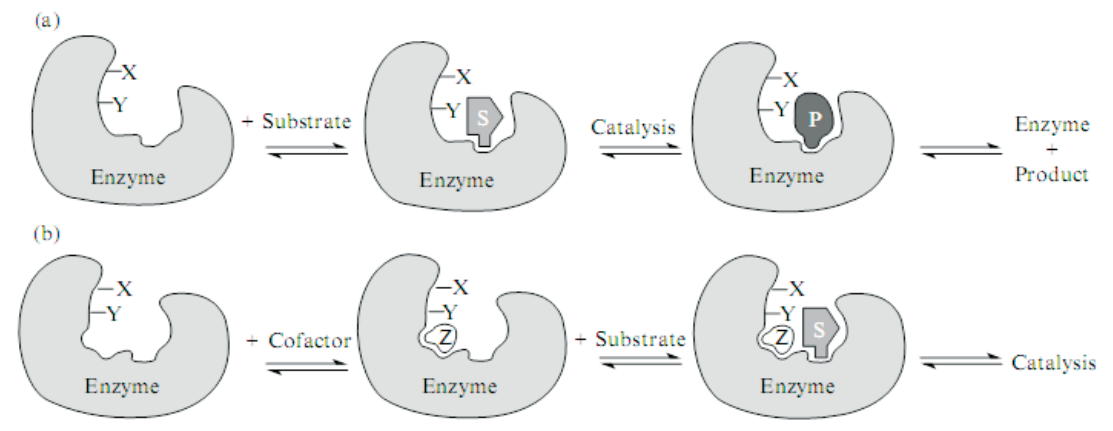

Gambar 4. Sisi Aktif Enzim

tonoplast dan terjadi kontak fasa dengan senyawa aktif gaultherin. Pelarut polar tersebut akan mendifusi ke luar sel daun dengan membawa gaultherin. Hal ini disebabkan oleh perbedaan kelarutan.

Enzim merupakan suatu molekul raksasa dengan berat molekul yang bervariasi antara 5000 Da-5 juta Da. Enzim termasuk dalam kelompok makromolekul yang lebih besar yakni protein dan terdiri dari rangkaian rantai linear asam-asam amino spesifik. Pada kondisi optimumnya enzim akan mengalami proses folding (Gambar 3). Proses terbentuknya susunan folding pada enzim merupakan proses spontan yang terjadi dalam hitungan detik (Bugg, 2004, Yang et al., 2004). Oleh karenanya, jika enzim gaultherase berada dalam keadaan folding, dan juga terjadi kerusakan pada membran tonoplast, mengakibatkan enzim tersebut mengkatalisis reaksi hidrolisa senyawa gaultherin menjadi metil salisilat. Hal ini menyebabkan perolehan senyawa aktif gaultherin relatif rendah.

Rangkaian asam amino pada enzim akan membentuk susunan tiga dimensi tertentu yang spesifik pada masing-masing jenis enzim (struktur tersier). Bagian dari struktur tersier enzim yang bertanggung jawab terhadap aktivitas katalitik enzim disebut sisi aktif. Jumlah sisi aktif dari suatu enzim mencapai 10-20\% dari volume total enzim (Bugg, 2004; Yang et al., 2004). Sisi aktif suatu enzim biasanya berupa suatu celah hidrofilik yang terdiri dari rangkaian rantai asam amino yang akan mengikat substrat (Gambar 4.a) atau mengikat suatu kofaktor (Gambar 4.b) dan mengkatalisis reaksi.

Proses folding pada enzim merupakan proses yang melibatkan masuknya rantai asam amino yang bersifat hidrofobik ke sisi bagian dalam dari enzim dan proses keluar atau bergesernya rantai asam amino yang bersifat hidrofilik ke bagian luar dari susunan tiga dimensi enzim.

\section{Identifikasi Senyawa aktif gaultherin}

Analisis lanjutan terhadap sampel bertujuan untuk memastikan bahwa yang teridentifikasi adalah gaultherin. Analisis FAB+ memunculkan bahwa pada peak yang muncul pada saat retensi 14 menit adalah senyawa yang memiliki molecular 
ion mass sebesar 469,0945 m/z. Massa tersebut merupakan massa molekul gaultherin $(446 \mathrm{~m} / \mathrm{z})$ ditambah dengan massa molekul sodium, yang seringkali muncul. Oleh karenanya, berdasarkan grafik hasil analisis FAB+ membuktikan bahwa sampel yang dianalisis benar mengandung gaultherin (analisis pada waktu retensi 14 menit).

\section{Studi Produktivitas Gaultherin}

Telaah produktivitas senyawa aktif gaultherin dengan penambahan drying agent berupa gelatin, kalsium klorida, dan sodium sulfat. Gambar 5 dan 6 menyajikan grafik hubungan antara penambahan drying agent pada berbagai konsentrasi etanol maupun konsentrasi dehidrasi osmosis terhadap kadar gaultherin. Meningkatnya konsentrasi drying agent maupun etanol menyebabkan perolehan gaultherin semakin besar, terutama dengan penambahan kalsium klorida. Hal ini dapat dijelaskan bahwa drying agent berfungsi sebagai pengering secara osmosis, yaitu proses pengambilan air dari suatu bahan yang dilakukan dengan menempatkan bahan pada larutan berkonsentrasi tinggi dimana di antara keduanya terdapat membran semipermiabel. Air dari larutan encer akan mendifusi melalui membran ke larutan yang lebih tinggi konsentrasinya terus-menerus hingga tercapai keadaan setimbang. Mengingat sifat membran semipermiabel yang hanya dapat dilewati air dan senyawa dengan berat molekul

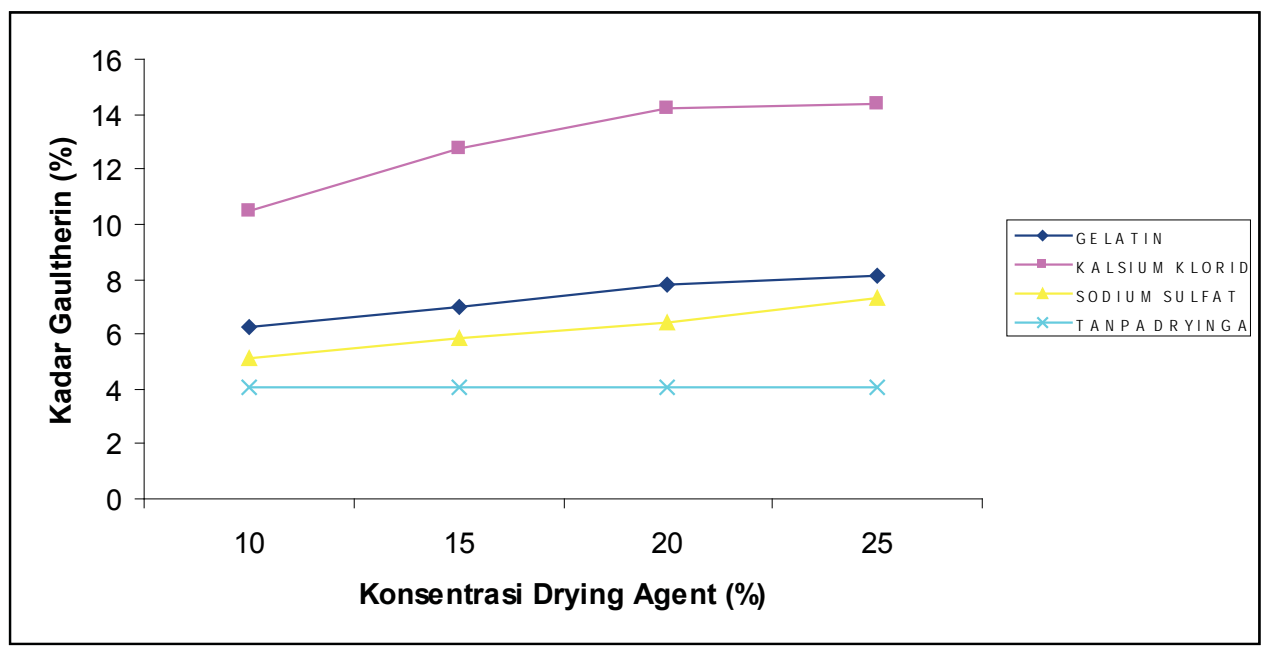

Gambar 5. Grafik Hubungan antara Konsentrasi Drying Agent dengan Kadar Gaultherin

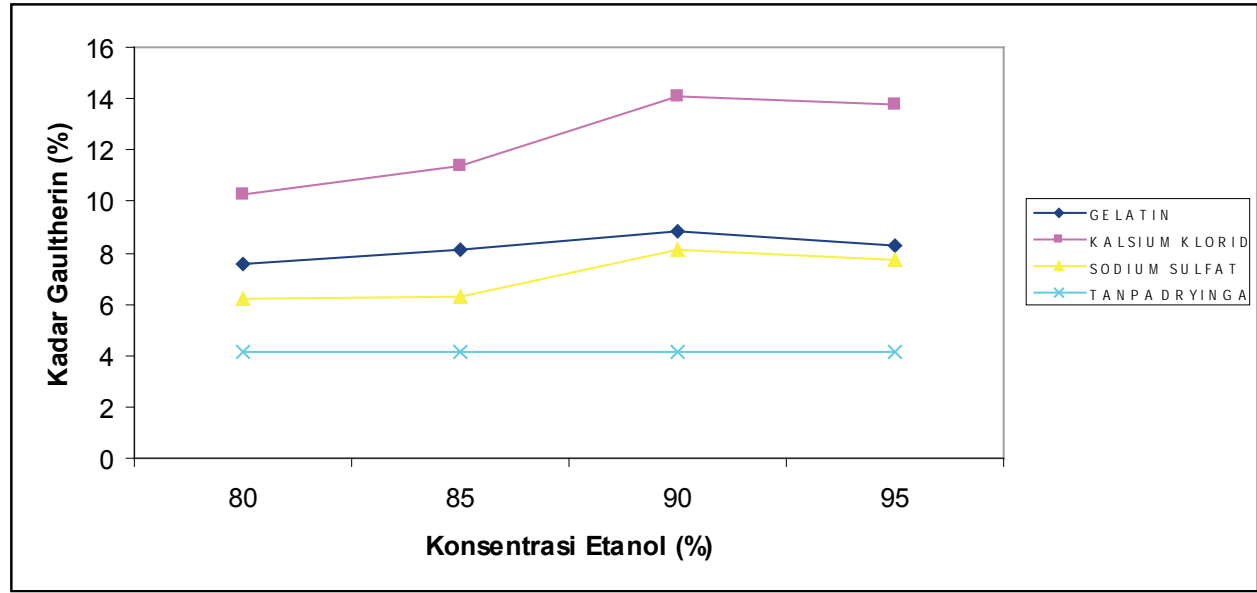

Gambar 6. Grafik Hubungan antara Konsentrasi Etanol dengan Kadar Gaultherin pada Konsentrasi Drying Agent 20\% 
kecil maka solut tidak dapat mendifusi melalui membran ke arah sebaliknya. Bilapun ada solut yang mendifusi, perpindahan massa yang terjadi sangat lambat, akibatnya kemungkinan terjadinya reaksi hidrolisa gaultherin menjadi metil salisilat relatif rendah. Perpindahan massa utama yang terjadi pada proses ini adalah perpindahan massa air ke larutan yang konsentrasinya tinggi (Silva et al., 2011).

Perpindahan massa air melalui membran semipermiabel dapat berlangsung karena adanya beda potensial kimia antara kedua larutan tersebut, dimana potensial kimia air di larutan encer lebih tinggi daripada potensial kimia air di larutan dengan konsentrasi tinggi. Fenomena ini dikenal dengan peristiwa osmosis (Cheryan et al., 1992). Potensial kimia merupakan fungsi konsentrasi, temperatur dan tekanan. Jika pada kondisi isothermal, maka potensial kimia hanya dipengaruhi oleh konsentrasi dan tekanan saja. Meningkatnya konsentrasi solut akan menurunkan potensial kimia solven (Lewicki et al., 1995, Eren et al., 2007).

\section{Penentuan Variabel Proses yang Paling Berpengaruh}

Tabel 3 dan 4 menyajikan perolehan senyawa aktif gaultherin pada berbagai variabel proses ekstraksi. Kajian desain eksperimental ini digunakan untuk menentukan variabel yang paling berpengaruh. Hasil perhitungan menunjukkan bahwa harga efek utama dan interaksi, diketahui bahwa variabel yang paling berpengaruh adalah $\mathrm{pH}$ dan konsentrasi etanol (efek BD positif terbesar).

Tabel 3. Harga Efek Utama dan Efek Interaksi pada Penentuan Variabel Berpengaruh

\begin{tabular}{llllllll}
\hline Efek & $\begin{array}{l}\text { Harga } \\
\text { Efek }\end{array}$ & Efek & $\begin{array}{l}\text { Harga } \\
\text { Efek }\end{array}$ & Efek & $\begin{array}{l}\text { Harga } \\
\text { Efek }\end{array}$ & $\begin{array}{l}\text { Efek } \\
\text { Efek }\end{array}$ \\
\hline a & 0.7775 & ad & 0.8175 & ae & 1.587 & ade & 0.06 \\
b & -0.275 & bd & 2.3087 & be & -0.495 & bde & 1.73 \\
ab & -0.165 & abd & 0.6675 & abe & -0.007 & abde & -0.427 \\
c & 1.3475 & cd & 0.4475 & ce & -0.19 & cde & -0.9125 \\
ac & -0.925 & acd & 0.395 & ace & 0.985 & acde & 0.8275 \\
bc & -1.1125 & bcd & 0.205 & bce & 0.6725 & bcde & -0.6475 \\
abc & -0.985 & abcd & -0.6075 & abce & 0.6825 & abcde & -0.08825 \\
d & 0.0425 & e & 1.2487 & de & 1.1875 & & \\
\hline
\end{tabular}

Tabel 4. Data Hasil Percobaan pada Penentuan Variabel Berpengaruh

\begin{tabular}{ccccccc}
\hline $\begin{array}{c}\text { Run } \\
\text { Ke- }\end{array}$ & A & B & $\begin{array}{c}\text { Variabel } \\
\text { C }\end{array}$ & D & E & Kadar gaultherin \\
\hline 1 & $10 \%$ & $80 \%$ & $5: 1$ & 7 & 30 & 8,40 \\
2 & $25 \%$ & $80 \%$ & $5: 1$ & 7 & 30 & 7,62 \\
3 & $10 \%$ & $95 \%$ & $5: 1$ & 7 & 30 & 11,5 \\
4 & $25 \%$ & $95 \%$ & $5: 1$ & 7 & 30 & 12,10 \\
5 & $10 \%$ & $80 \%$ & $10: 1$ & 7 & 30 & 10,75 \\
6 & $25 \%$ & $80 \%$ & $10: 1$ & 7 & 30 & 10,90 \\
7 & $10 \%$ & $95 \%$ & $10: 1$ & 7 & 30 & 12,46 \\
8 & $25 \%$ & $95 \%$ & $10: 1$ & 7 & 30 & 6,22 \\
9 & $10 \%$ & $80 \%$ & $5: 1$ & 9 & 30 & 7,31 \\
10 & $25 \%$ & $80 \%$ & $5: 1$ & 9 & 30 & 7,27 \\
11 & $10 \%$ & $95 \%$ & $5: 1$ & 9 & 30 & 5,20
\end{tabular}


Lanjutan Tabel 4

\begin{tabular}{ccccccc}
\hline $\begin{array}{c}\text { Run } \\
\text { Ke- }\end{array}$ & $\mathbf{A}$ & $\mathbf{B}$ & $\mathbf{C}$ & $\mathbf{D}$ & $\mathbf{E}$ & Kadar gaultherin \\
\hline 12 & $25 \%$ & $95 \%$ & $5: 1$ & 9 & 30 & 9,82 \\
13 & $10 \%$ & $80 \%$ & $10: 1$ & 9 & 30 & 12,09 \\
14 & $25 \%$ & $80 \%$ & $10: 1$ & 9 & 30 & 10,15 \\
15 & $10 \%$ & $95 \%$ & $10: 1$ & 9 & 30 & 10,90 \\
16 & $25 \%$ & $95 \%$ & $10: 1$ & 9 & 30 & 8,05 \\
17 & $10 \%$ & $80 \%$ & $5: 1$ & 7 & 60 & 7,15 \\
18 & $25 \%$ & $80 \%$ & $5: 1$ & 7 & 60 & 11,75 \\
19 & $10 \%$ & $95 \%$ & $5: 1$ & 7 & 60 & 5,8 \\
20 & $25 \%$ & $95 \%$ & $5: 1$ & 7 & 60 & 11,47 \\
21 & $10 \%$ & $80 \%$ & $10: 1$ & 7 & 60 & 11,02 \\
22 & $25 \%$ & $80 \%$ & $10: 1$ & 7 & 60 & 7,40 \\
23 & $10 \%$ & $95 \%$ & $10: 1$ & 7 & 60 & 8,50 \\
24 & $25 \%$ & $95 \%$ & $10: 1$ & 7 & 60 & 8,3 \\
25 & $10 \%$ & $80 \%$ & $5: 1$ & 9 & 60 & 8,4 \\
26 & $25 \%$ & $80 \%$ & $5: 1$ & 9 & 60 & 9,08 \\
27 & $10 \%$ & $95 \%$ & $5: 1$ & 9 & 60 & 12,9 \\
28 & $25 \%$ & $95 \%$ & $5: 1$ & 9 & 60 & 6,8 \\
29 & $10 \%$ & $80 \%$ & $10: 1$ & 9 & 60 & 13,05 \\
30 & $25 \%$ & $80 \%$ & $10: 1$ & 9 & 60 & 9,4 \\
31 & $10 \%$ & $95 \%$ & $10: 1$ & 9 & 60 & 12,2 \\
32 & $25 \%$ & $95 \%$ & $10: 1$ & 9 & 60 & \\
\hline
\end{tabular}

\section{Optimasi pH pada Mixed-Drying Extraction Proses Inaktivasi Enzim Gaultherase}

Gambar 7 menunjukkan bahwa semakin besar $\mathrm{pH}$ ekstraksi (pengaturan dengan buffer), akan meningkatkan perolehan senyawa aktif gaultherin. Namun demikian, peningkatan $\mathrm{pH}$ lebih lanjut menyebabkan produksi gaultherin menurun. Kondisi optimum mixed-drying extraction inaktivasi enzim tercapai pada $\mathrm{pH} 8$ dengan kadar senyawa aktif gaultherin sebesar $14,46 \%$ dan persamaan regresi $\mathrm{y}=-4,8074 \mathrm{x}^{2}+$ $78,301 \mathrm{x}-305,28$. Hal ini bisa dijelaskan bahwa gaultherase merupakan jenis enzim hydrolase, yang memiliki aktivitas optimum disekitar $\mathrm{pH}$ larutan asam lemah. Oleh karenanya, pada kondisi mixed-drying extraction basa lemah menyebabkan enzim gaultherase mengalami unfolding, akibatnya akan mereduksi reaksi hidrolisa gaultherin menjadi metil salisilat yang dikatalisis oleh enzim gaultherase.

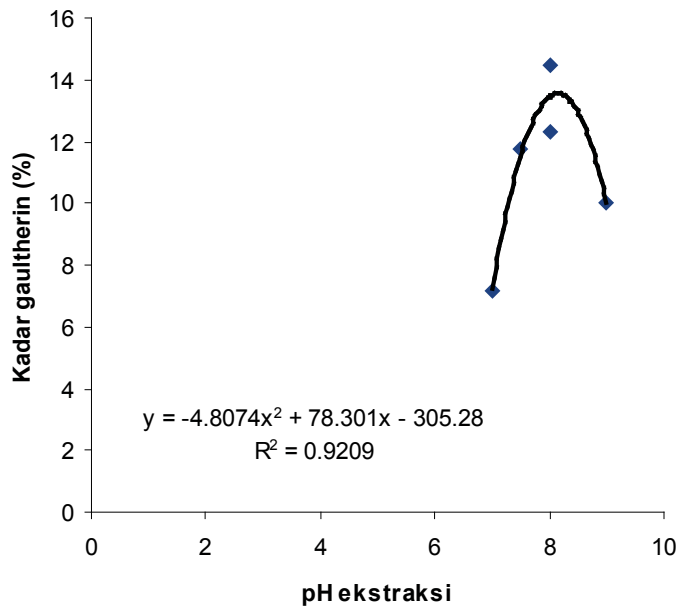

Gambar 7. Grafik Hubungan antara pH Ekstraksi dengan Kadar Gaultherin

\section{Optimasi Pelarut pada Mixed-Drying Extraction Pada Inaktivasi Enzim Gaultherase}

Gambar 8 menyajikan grafik hubungan antara konsentrasi etanol terhadap kadar gaultherin. Semakin besar konsentrasi pelarut, gaultherin 


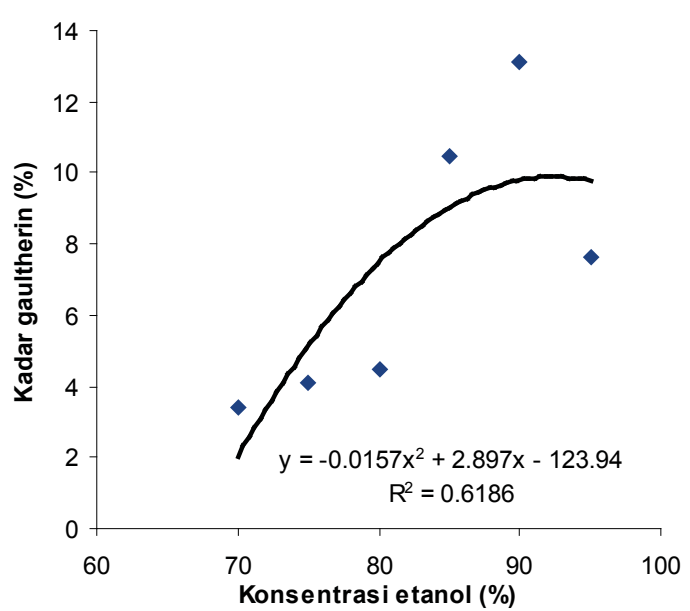

Gambar 8. Grafik Hubungan antara Konsentrasi Etanol dengan Kadar Gaultherin

yang terekstrak semakin meningkat. Hal ini terjadi karena memperbesar konsentrasi pelarut berarti memperbesar fasa kontinyu, akibatnya fraksi volum fasa cair yang terdispersi semakin kecil dan diameter partikel juga mengecil. Dengan mengecilnya diameter partikel, maka akan memperluas kontak antar fasa yang disebabkan semakin meningkatnya solut yang terseret dalam fasa pelarut. Akan tetapi, peningkatan konsentrasi senyawa polar lebih lanjut menyebabkan perolehan senyawa aktif gaultherin menurun. Hal ini dimungkinkan, pada konsentrasi etanol diatas $90 \%$, menyebabkan sebagian diluen terikut ke fasa kontinyu karena terjadi peningkatan kelarutan. Produksi gaultherin secara optimum tercapai pada konsentrasi etanol 90\% dengan perolehan senyawa aktif sebesar $13,10 \%$.

\section{SIMPULAN}

Hasil riset menunjukkan bahwa variabel proses inaktivasi enzim gaultherase melalui mixed-drying extraction yang paling berpengaruh adalah $\mathrm{pH}$ dan konsentrasi etanol. Semakin besar pH ekstraksi, akan meningkatkan perolehan senyawa aktif gaultherin. Kondisi optimum inaktivasi enzim melalui mixed-drying extraction tercapai pada $\mathrm{pH} 8$ dengan kadar senyawa aktif gaultherin sebesar $14,46 \%$. Semakin besar konsentrasi pelarut, gaultherin yang terekstrak semakin meningkat, namun peningkatan konsentrasi etanol diatas 90\%, menyebabkan perolehan senyawa aktif gaultherin menurun. Produksi gaultherin secara maksimum tercapai pada konsentrasi etanol 90\% dengan perolehan senyawa aktif sebesar $13,10 \%$.

\section{UCAPAN TERIMA KASIH}

Pada kesempatan ini, penulis mengucapkan terima kasih yang sebesar-besarnya kepada DP2M-DIKTI atas dukungan dana dalam kegiatan Penelitian Hibah Bersaing 2014.

\section{DAFTAR PUSTAKA}

Bugg, T.D.H., 2004. Diverse Catalytic Activities in the A $\beta$-hydrolase Family of Enzymes: Activation of $\mathrm{H}_{2} \mathrm{O}, \mathrm{HCN}, \mathrm{H}_{2} \mathrm{O}_{2}$, and $\mathrm{O}_{2}$, Bioorganic Chemistry, 32(5), 367-375.

Cheryan, M. and Nichols, D.J., 1992. Modelling of Membrane Processes : In Mathematical Modelling of Food Processes, edited by S.Thorne, Elsevier, London, UK, 49-98.

Eren, I. and Ertekin, F.K., 2007. Optimization of Osmotic Dehydration of Potato using Response Surface Methodology, Journal of Food Engineering, 79, 344-352.

Hernani, 2004. Gandapura: Pengolahan, Fitokimia, Minyak Atsiri dan Daya Herbisida. Buletin TRO, XV (2), Balai Besar Penelitian dan Pengembangan Pascapanen Penelitian.

Hoffman, E.J., 2007. Cancer and the Search for Selective Biochemical Inhibitors, Second Ed., CRC Press.

Kusumo, P. K. dan Yulianto, M.E., 2013. Pengaruh Drying Agent pada Ekstraksi dan Inaktivasi Enzim Gaultherase Simultan dari Gandapura (Gaultheria fragantissima), Seminar Nasional Teknik Kimia Kejuangan, UPN Yogyakarta.

Lewicki, P. and Lenart, A., 1995. Osmotic Dehidration of Fruits and Vegetables. Handbook of Industrial Drying, (2 nd ed.), New York: Marcel Decker, Inc., 691-713.

Linjakumpu, T., Hartikainen, S., Klaukka, T., Veijola, J., Kivelä, S.L., and Isoaho, R., 2002. Use of Medications and Polypharmacy are Increasing Among the Elderly. Journal of Clinical Epidemiology, 55 (8), 809-817.

Manurung, R., 2002. Minyak Atsiri, Peluang Bisnis yang Belum Digarap Optimal, Harian Umum Sore Sinar Harapan.

Mauludi, L., 2003. Kelayakan Usaha Pengolahan Minyak Gandapura di Kabupaten Wonosobo Jawa Tengah, Buletin TRO, XIV (2), Balai Penelitian Tanaman Rempah dan Obat. 
Poulev, A.A., O’Neal, J.M., Logendra, S., Pouleva, R.B., Timeva, V., Garvey, A.S., Gleba, D., Jenkins, I.S., Halpern, B.T., Kneer, R., Cragg, G.M., and Raskin, I., 2003. Elicitation, a New Window into Plant Chemodiversity and Phytochemical Drug Discovery, Journal of Medicinal Chemistry, 46, 2542-2547.

Ribnicky, D.M., Poulev, A.A., and Raskin, I., 2002. Recovery of Gaultherin from Plants, U.S. Patents, No. 2002/0031562 A1.

Ribnicky, D.M., Poulev A.A., and Raskin, I., 2003. The Determination of Salicylates in Gaultheria Procumbens for Use as a Natural Aspirin Alternative, Journal of Nutraceuticals, Functional and Medical Food, 4 (1).
Ribnicky, D.M., Poulev A.A., and Raskin, I., 2006. Methods of Administering GaultherinContaining Compositions, U.S. Patent, No. 7.033.618.

Silva, K.D.S., Caetano, L.C., Garcia, C.C., Romero, J.T., Santos, A.B., and Mauro, M.A., 2011. Osmotic Dehydration Process for Low Temperature Blanched Pumpkin, Journal of Food Engineering, 105, 56-64.

Yang, X., Wang, M., and Fee, M.C., 2004. Analysis of Protein Folding and Function using Backbone Modified Proteins, Bioorganic Chemistry, 32(5), 438- 449 . 